\title{
SCAFFOLDING AS AN INTERACTIVE METHOD IN TEACHING A FOREIGN LANGUAGE
}

\section{Azizova Gulnora Shakirdjanovna}

Senior Teacher The National Institute Of Fine Arts And Design Named After Kamoliddin Bekhzod, Uzbekistan

\section{ABSTRACT}

The article discusses the concept of scaffolding, its history and application in methodology and pedagogy, as well as the main characteristics for the successful use of this technique. The detailed analysis of this technique is given in the article. The experiment is examined as an example of this technique.

KEYWORDS: - Learnability, immediate development zone, scaffolding.

\section{INTRODUCTION}

The process of learning a language does not really depend on the supervising teacher. Much depends on your relationship with the language and learning it. It is important to remember that it is not enough to enroll in courses and attend classes to learn a language. Also, language lessons are not enough to fill your vocabulary and learn grammar to inspire yourself, if you don't learn a foreign language, your future prospects are very bleak. Language learning means integration into another culture.

The purpose of the article. Innovative-industrial economy, informatization of society, harmonization of educational space and radical introduction of international standards are changes in human consciousness and behavior. Vocational-oriented foreign language learning is now recognized as a priority in the renewal of education. The essence of vocational-oriented education is the formation of additional professional knowledge and professionally important qualities of the individual, consisting of integration with special disciplines for a foreign language. In this case, the foreign language serves as a means of professional development, personal and professional development of students is necessary and a condition for success.

The article focuses on new interactive approaches (especially scaffolding) to foreign language learning and teaching, which act as a means of improving professional competition.

Scaffolding was first introduced to the educational process by Bruno in 1976, and then developed by Lev Vygotsky for the first time in education with the concept and theory of the "Proximal Development Zone (ZPD)" (1978).

Scaffolding is perceived by more qualified people 
CURRENT RESEARCH JOURNAL OF PHILOLOGICAL SCIENCES 2(7): 10-12,

May 2021 DOI: https://doi.org/10.37547/philological-crjps-02-07-03

ISSN 2767-3758

(C)2021 Master Journals

\section{Crossref do) 8 Google}

Accepted15thJuly, 2021 \& Published 20thJuly, 2021

or professionals as a temporary aid to students during the learning process (Wood, Bruner and Ross: 1976).

The proximal developmental zone (ZPD) is defined as: the distance between the actual level of development determined by independent problem solving and the level of potential development to be determined by problem solving under adult guidance, or the level of collaboration with more capable peers. (Vygotsky, 1978 p. 86).

The essence of the technology is as follows: using special cognitive or problem-solving tasks and instructions, the teacher is expected to discover a new experience and apply it in practice in various forms. For example, it can be expressed in the form of blocks, keys, or leading questions.

To help move through the proximal developmental zone (ZPD), teachers are encouraged to pay attention to three important components that help the learning process:

1. The presence of a person with knowledge and skills other than the student

2. Social relationships with a skilled tutor that allow the student to observe and practice their skills.

3. Scaffolding or supportive activities by the teacher, or a peer with more knowledge to support the student.

The terms scaffolding and ZPD have become synonymous in the literature. However, it should be noted that Vygotsky never used the term in writing. It is important to note that this term was introduced by Wood, Bruner, and Ross (1976).

Scaffolding is an activity performed by a teacher or a more qualified peer who should lead through the proximal developmental zone.

The scaffolding method helps the student to complete a new task. It should be noted that scaffolding, cooperative learning, and guided learning have the same meaning in the literature. This method is an important feature of effective teaching, in which adults change the level of assistance in response to students 'performance levels. In the classroom, scaffolding can involve the formation of skills, pointing, adapting topics and materials, and a variety of activities (Kopple \& Bredekamp, 2009).

Learning a foreign language is also associated with a new language environment, the discovery of a new cultural reality. A foreign language is just a new set of words and rules, a new world that allows you to promote the language more, and it takes time to learn the language in this regard.

Refer to these instructions for guidance, evaluate the student's current knowledge and experience for the curriculum. Link content to things you already understand or can do. Use oral communication and try to help students. Give them a break and more ongoing situations, give them the opportunity to use connectors. (Silver, 2011).

As far as we know, in addition to grammatical errors in oral speech, another problem is the complete forgetfulness of the use of connecting words. When a student talks about a topic, the teacher observes it grammatically, ensuring that the sentences are connected and that he does not use the same kind of tenses when covering a topic.

It is difficult to learn to speak English, and those who have been learning English for years find it more difficult to speak. People who learn a language for other reasons may have mastered the grammar and rules of the language. But it is not easy for such learners to speak English. Experience is required to develop speaking skills. In this article, I want to write about how to develop the ability to speak quickly and expressively with a certain level of knowledge of English. I think that most learners who are 
CURRENT RESEARCH JOURNAL OF PHILOLOGICAL SCIENCES 2(7): 10-12,

May 2021 DOI: https://doi.org/10.37547/philological-crjps-02-07-03

ISSN 2767-3758

(C)2021 Master Journals

Crossref dof 81 Google

Accepted15thJuly, 2021 \& Published 20thJuly, 2021

familiar with English grammar but have difficulty speaking are eager to develop their skills in this area as much as possible. To develop speaking skills, you must first pay close attention to pronunciation. It is recommended to read the words correctly with transcription. It is also a good idea to watch audio or movies that are played in pure English.

Following Silver's instructions, I used the scaffolding method to develop oral speech. This method enriches students' speaking skills with connectors and helps them express themselves more clearly.

For example: the teacher asks the student a question

T: Tell me about some places which you like in your country.

S: In my country I like parks. Among them, I like Aqua Park.

T: Why do you like Aqua Park?

$\mathrm{S}$ : Because it`s entertaining. There is various kind of swimming pools.

T: So...

Q: So, I took pleasure

T: However, ...

S: However, there is a crowd of people, I can relax.

In this way, the connectors for the student are listed where appropriate. This activity improves the student's speaking skills and thinking. Because in the process of continuing the story, the student must continue to speak after each new link, in accordance with this link. Of course, the student comes across some difficulties, and it should be noted that this method is effective for the student.

In summary, in this pedagogical sequence, we can consider the teacher as appropriate steps to support, guide, motivate, and assist students in the learning process.

\section{REFERENCES}

1. Ananiev B. G. On the problems of modern human knowledge. St. Petersburg.: Peter, 2001. - 272 p.

2. Instructional scaffolding: Reading and writing as natural language activities. Language Arts, 60(2), (pp. 168-175). Bruner, J. S. (1978).

3. The Role of Dialogue in Language Acquisition. In A. Sinclair, R. J. Jarvelle, \& W. J. M. Levelt (Eds.), The Child"s Concept of Language. New York: Springer-Verlag. De Gerrero, M. C., \& Villamil, O. S. (2000).

4. Activation the ZPD: Mutual scaffolding in L2 Peer Revision. Modern Language Journal, 84(1), (pp. 51-68). Donato, R (1994).

5. Collective Scaffolding in Second Language Learning. In J.P. Lantolf \& G. Appel (Eds), Vygotskian Approaches to Second Language Research, (pp.33-56). Ellis, R. (2003).

6. Task based language learning and teaching. Oxford: Oxford University Press. Gibbons Pauline. Scaffolding Language, Scaffolding Learning: Teaching Second Language Learners in the Mainstream Classroom. Portsmouth, NH: Heinemann, 2002. Jones, Leo (2007). 